\title{
STATEMENT FROM THE DIRECTOR OF THE W. E. B. DU BOIS INSTITUTE
}

In 1903, William Edward Burghardt Du Bois famously predicted that the problem of the twentieth century would be the problem of the color line. Indeed, during the past century, matters of race were frequently the cause of intense conflict and the stimulus for public policy decisions not only in the United States, but throughout the world. The founding of the Du Bois Review: Social Science Research on Race at the beginning of the twenty-first century acknowledges the continuing impact of Du Bois's prophecy, his pioneering role as one of the founders of the discipline of sociology in the American academy, and the considerable work that remains to be done as we confront the "problem" that Du Bois identified over a century ago.

It is a commonplace in the academy today that "race" is a social construction; but in the name of that social construction human beings have organized themselves into sub-communities, they have insisted on their right to celebrate their self-defined identities, and they have also drawn upon these identities to divide, to maim, to rape and kill. It is to consider this remarkable array of manifestations of race that we have launched this journal.

The W. E. B. Du Bois Institute for African and African American Research at Harvard University is the institutional home of the $D u$ Bois Review. This is most appropriate for several reasons. It was at Harvard in 1895 that Du Bois earned a Ph.D. in history - the first African American to do so-and laid the foundation for his work as a historian and sociologist through his studies with philosophers George Santayana and William James and historian Alfred Bushnell Hart. Du Bois's graduate work at Harvard followed two years of study with the social scientists Gustav Schmoller, Adolf Wagner, Heinrich von Treitschke, and Max Weber at the Friedrich Wilhelm University in Berlin, one of the early sites where the discipline of sociology was developed. In 1899, based on research commissioned by the University of Pennsylvania, Du Bois published his groundbreaking work, The Philadelphia Negro, the first major sociological survey of an African American community.

The concept of race has been a central shaping force in American history, and continues to affect all aspects of American culture and society. The editors of the Du Bois Review-sociologist Lawrence D. Bobo and political scientist Michael C. Dawson, both professors at Harvard University_define the social sciences as embracing not only anthropology, economics, political science, psychology, and sociology, but also communications, history (and related fields), law, and public policy. Simply

Du Bois Review, 1:1 (2004) 1-2.

(C) 2004 W. E. B. Du Bois Institute for African and African American Research 1742-058X/04 \$9.50 DOI: $10.1017 / \mathrm{S} 1742058 \times 04040019$ 


\section{Foreword}

put, the Du Bois Review is a journal dedicated to analyzing the complex role of race in society. Its editorial mission is to publish the most rigorous and provocative thinking about race in the academy today. The Du Bois Institute is honored to join forces with Cambridge University Press in publishing the Du Bois Review.

Henry Louis Gates, 7 r. Director

W. E. B. Du Bois Institute for African and African American Research Harvard University

Corresponding author: Professor Henry Louis Gates, Jr., Department of African and African American Studies, 12 Quincy Street, Harvard University, Cambridge, MA 02143. E-mail: jkendall@fas.harvard.edu (Administrative Asst.) 